\title{
Evaluasi kepatuhan RSU GMIM Bethesda Tomohon dalam penempatan tenaga kesehatan sesuai Undang-Undang Nomor 36 Tahun 2014
}

\author{
${ }^{1}$ Endah Tuladhani, ${ }^{2}$ Erwin G. Kristanto, ${ }^{3}$ Jantje Pongoh
}

\author{
${ }^{1}$ Program studi Ilmu Kesehatan Masyarakat Bidang Minat Kajian Administrasi Rumah Sakit \\ Pascasarjana Universitas Sam Ratulangi Manado \\ ${ }^{2}$ Fakultas Kedokteran Universitas Sam Ratulangi Manado \\ ${ }^{3}$ Fakultas Pertanian Universitas Sam Ratulangi Manado \\ Email: endahtuladhani11@gmail.com
}

\begin{abstract}
Recruitment of health personnels is included in the purpose of UU Nomor 36 tahun 2014. This UU states that all health personnels should have the STR and SIP. Moreover, SPK graduated medical assistants are not longer accepted as professional workers. As one of the type $\mathrm{C}$ hospitals in Tomohon, the numbers and types of competence of health personnels at GMIM Bethesda Hospital have to meet the requirement set out in PERMENKES no 56 RI 2014, which is about the permission of hospital operation. This study was aimed to evaluate the compliance of GMIM Bethesda Hospital in recruitment of health personnels and medical assistants in their respective fields of health services, in accordance with its competence and authority based on UU Nomor 36 tahun 2014. This study used a qualitative method. Thorough interviews and document observation were performed to obtain information about the the management of GMIM Bethesda Hospital in placing their health personnels in accordance with the UU No 36 tahun 2014. The results showed that the recruitment of health personnels of GMIM Bethesda Hospital was in accordance with UU No 362014 except for clinical pathologists, dental specialists, and pharmacists that are still lacking, and also for the great numbers of SPK graduated personnels who were still working at the hospital. Conclusion: In general, health personnels of GMIM Bethesda hospital were in accordance with UU No 36 tahun 2014.
\end{abstract}

Keywords: health personnels, recruitment

\begin{abstract}
Abstrak: Penempatan tenaga kesehatan termasuk dalam salah satu tujuan dari UU Nomor 36 tahun 2014. RSU GMIM Bethesda sebagai salah satu rumah sakit di Kota Tomohon harus memenuhi persyaratan sebagaimana ditetapkan dalam Permenkes RI No 56 tahun 2014 terkait dengan izin operasional rumah sakit dan sebagai persyaratan rumah sakit yang telah terakreditasi tipe C. Penelitian ini bertujuan untuk mengevaluasi kepatuhan RSU GMIM Bethesda dalam menempatkan tenaga kesehatan dan asisten tenaga kesehatan di masingmasing bidang pelayanan kesehatan sesuai kompetensi dan kewenangannya berdasarkan UU No 36 tahun 2014. Penelitian ini menggunakan metode kualitatif melalui wawancara mendalam dan observasi dokumen untuk mendapatkan informasi mengenai manajemen rumah sakit Bethesda dalam menempatkan tenaga kesehatan sesuai ketentuan UU No 36 tahun 2014 yaitu setiap tenaga kesehatan harus memiliki STR dan SIP dan tidak adanya lagi asisten tenaga kesehatan lulusan SPK yang menjadi tenaga profesi. Hasil penelitian menunjukkan bahwa penempatan tenaga kesehatan di RSU GMIM Bethesda sudah sesuai dengan UU No 36 tahun 2014 kecuali tenaga dokter spesialis patologi klinik, dokter spesialis gigi, dan apoteker masih kurang, juga masih terdapat banyak tenaga lulusan SPK yang masih bekerja di rumah sakit ini. Simpulan: Penempatan tenaga kesehatan di RSU GMIM Bethesda telah sesuai dengan UU No 36 tahun 2014.
\end{abstract}

Kata kunci: tenaga kesehatan, penempatan tenaga kesehatan 
Rumah sakit merupakan suatu organisasi padat karya yang membutuhkan banyak tenaga dan profesi dari berbagai disiplin ilmu. Rumah sakit ialah salah satu bentuk sarana kesehatan bagi masyarakat, baik yang diselenggarakan oleh pemerintah maupun swasta yang berfungsi sebagai pelaku upaya kesehatan dasar ataupun kesehatan rujukan dan atau melakukan upaya kesehatan penunjang. ${ }^{7}$

Sumber daya manusia merupakan faktor yang sangat berperan dalam suatu organisasi untuk memberikan pelayanan publik. Pemberi pelayanan kesehatan masyarakat (rumah sakit) dituntut untuk memiliki sumber daya manusia yang berkualitas sehingga mampu bersaing dengan pemberi pelayanan kesehatan lainnya. Rumah sakit juga dituntut untuk mampu mengelola sumber daya manusia yang dimiliki, sehingga dapat mencapai tujuan rumah sakit uyang efektif dan efisien dengan meningkatkan kinerja maksimal yang dimiliki oleh rumah sakit tersebut. ${ }^{8}$

Evaluasi dilakukan untuk melihat kepatuhan RSU GMIM Bethesda sesuai UU Nomor 362014 yang bertujuan untuk memberikan kepastian hukum dan perlindungan kepada tenaga kesehatan dan masyarakat dalam meningkatkan mutu penyelenggaraan upaya kesehatan. Hasil pengamatan peneliti sebagai observasi awal di RSU GMIM Bethesda sebagian perekrutan tenaga kesehatan yang diusulkan oleh RSU GMIM Bethesda berbeda dengan hasil perekrutan tenaga kesehatan yang ditetapkan oleh Yayasan Medika. Selain itu jenis dan jumlah tenaga kesehatan masih belum sesuai dengan ketentuan perundang-undangan dengan masih banyaknya tenaga lulusan SPK dan belum terpenuhi beberapa dokter spesialis patologi klinik dan gigi. Jenis tenaga kesehatan yang dibutuhkan tidak ada karena belum ada perguruan tinggi yang menghasilkan tenaga kesehatan yang dibutuhkan tersebut. Dari hasil data yang diperoleh tersebut maka yang menjadi masalah penelitian ini ialah bagaimana kepatuhan RSU GMIM Bethesda Tomohon dalam penempatan tenaga kesehatan sesuai dengan Undang-undang nomor 36 tahun 2014.

\section{METODE PENELITIAN}

Jenis penelitian ini ialah kualitatif yang dilakukan di RSU GMIM Bethesda Kota Tomohon yang bersifat investigasi secara mendalam terhadap 5 (lima) informan yang terdiri dari 1 Direktur Rumah Sakit, 1 Wakil Direktur Sumber Daya Manusia, 1 Wakil Direktur pelayanan Medis, 1 tenaga dokter, dan 1 Kepala Bidang Keperawatan. Sumber data primer diperoleh melalui wawancara mendalam dan observasi lapangan sedangkan data sekunder diperoleh dari laporan dokumen yang ada di rumah sakit. Data dirangkum dalam bentuk matriks dari hasil wawancara, kemudian disajikan dalam bentuk narasi. Validasi data dilakukan dengan cara triangulasi sumber dan triangulasi metode.

\section{HASIL DAN BAHASAN \\ Penempatan tenaga kesehatan di RSU GMIM Bethesda}

Amanat Undang-Undang No. 36 tahun 2014 adalah pendayagunaan tenaga kesehatan yang mengatur penempatan tenaga kesehatan di rumah sakit sesuai dengan syarat dan ketentuan yang ditetapkan menurut jumlah dan jenis tenaga kesehatannya berdasarkan kompetensi dan kewenangan tenaga kesehatan. Tenaga kesehatan harus memiliki kualifikasi minimum Diploma Tiga, kecuali tenaga medis dan asisten tenaga kesehatan (contohnya SPK) tidak boleh menjadi tenaga profesi dan hanya dapat bekerja menjadi tenaga pendamping/asisten tenaga kesehatan. Setiap tenaga kesehatan harus memiliki STR dari konsil masing-masing kolegium dari tenaga kesehatan, dan setelah memenuhi persyaratan akan diterbitkan SIP dari Dinas Kesehatan Kabupaten/Kota. ${ }^{5}$

Menurut Ardana et al. ${ }^{1}$ penempatan adalah proses mencocokkan atau membandingkan kualifikasi yang dimiliki dengan persyaratan pekerjaaan dan sekaligus memberikan tugas, pekerjaan kepada calon 
pegawai untuk dilaksanakan. Ketepatan dalam menempatkan pegawai dengan kesesuaian kompetensi dan kewenangannya menjadi keharusan di RSU GMIM Bethesda dengan melihat gelar pendidikan harus linier dengan kompetensi dan penempatan kerjanya. Tahapan dalam proses penerimaan hingga penempatan tenaga kesehatan dimulai dari seleksi berkas ijazah hingga tes tertulis/praktek dari Yayasan Medika kemudian pihak personalia rumah sakit akan memeriksa STR dan SIP dan dilanjutkan dengan test kredensial oleh tim. Berdasarkan usulan dari rumah sakit akan kebutuhan tenaga kesehatan yang diajukan ke Yayasan, tenaga kesehatan yang diterima akan dikelompokkan sesuai dengan ketentuan perundang-undangan untuk RSU GMIM Bethesda yang telah terakreditasi tipe $\mathrm{C}$.

Berdasarkan hasil wawancara mendalam dan observasi dokumen di RSU GMIM Bethesda semua tenaga kesehatan sudah memenuhi persyaratan dan ditempatkan di bidang-bidang pelayanan kesehatan sesuai dengan kompetensi dan kewenangannya. Asisten tenaga kesehatan (SPK) sudah tidak menjadi tenaga profesi yaitu sebagian besar sedang mengikuti pendidikan Diploma Tiga, sedangkan yang tidak mengikuti pendidikan telah ditempatkan di bagian administrasi.

\section{Jenis tenaga kesehatan di RSU GMIM GMIM Bethesda}

Kualifikasi dan pengelompokkan tenaga kesehatan berdasarkan UU No.36 tahun 2014 dikelompokkan dalam 13 jenis tenaga kesehatan,yaitu: ${ }^{5}$

a. Tenaga medis: dokter, dokter gigi, dokter spesialis, dan dokter gigi spesialis

b. Tenaga psikologis klinis: psikolog klinis

c. Tenaga keperawatan: berbagai jenis perawat

d. Tenaga kebidanan: bidan

e. Tenaga kefarmasian: apoteker dan tenaga teknis kefarmasian

f. Tenaga kesehatan masyarakat: epidemiologi kesehatan, tenaga promosi kesehatan dan ilmu prilaku, pembimbing kesehatan kerja, tenaga administrasi dan kebijakan kesehatan, tenaga biostatistik dan kependudukan, serta tenaga kesehatan reproduksi dan keluarga

g. Tenaga kesehatan lingkungan: tenaga sanitasi lingkungan, entomolog kesehatan, dan mikrobiolog kesehatan

h. Tenaga gizi: nutrisionis dan dietisien

i. Tenaga keterapian fisik: fisioterapis, okupasi terapis, terapis wicara, dan akupuntur

j. Tenaga keteknisian medis: perekam medis dan informasi kesehatan, teknik kardiovaskuler, teknisi pelayanan darah, refraksionis optisien/optometris, teknisi gigi, penata anestesi, terapis gigi dan mulut, dan audiologis.

k. Tenaga teknik biomedika: radiografer, elektromedis, ahli teknologi laboratorium medik, fisikawan medik, radioterapis, ortotik prostetik

1. Tenaga kesehatan tradisional ramuan dan tenaga kesehatan tradisional ketrampilan.

m. Tenaga kesehatan lainnya

RSU GMIM Bethesda sudah memiliki pelayanan sesuai persyararatan untuk tipe C, meliputi: pelayanan medik, pelayanan kefarmasian, pelayanan keperawatan dan kebidanan, pelayanan penunjang klinik, pelayanan penunjang nonklinik, dan pelayanan rawat inap. ${ }^{6}$

Pelayanan medik sebagaimana dimaksud dalam pasal 36 huruf a, dalam Permenkes RI nomor 56 tahun 2014 paling sedikit terdiri dari: ${ }^{6}$

a. Pelayanan gawat darurat, yang harus diselenggarakan 24 (dua puluh empat) jam sehari secara terus menerus.

b. Pelayanan medik umum yang meliputi pelayanan medik dasar, medik gigi mulut, kesehatan ibu dan anak, dan keluarga berencana

c. Pelayanan medik spesialis dasar, yang meliputi pelayanan penyakit dalam, kesehatan anak, bedah, serta obstetrik dan ginekologi

d. Pelayanan medik spesialis penunjang yang meliputi pelayanan anestesiologi, radiologi, dan patologi klinik

e. Pelayanan medik spesialis gigi dan 
mulut yang paling sedikit berjumlah satu pelayanan

f. Pelayanan kefarmasian meliputi pengelolaan sediaan farmasi, alat kesehatan dan bahan medis habis pakai, dan pelayanan farmasi klinik

g. Pelayanan keperawatan dan kebidanan meliputi asuhan keperawatan dan asuhan kebidanan

h. Pelayan penunjang klinik meliputi bank darah, perawatan intensif untuk semua golongan umur dan jenis penyakit, gizi, sterilisasi instrument dan rekam medik

i. Pelayanan penunjang nonklinik meliputi laundri/linen, jasa boga/dapur, tehnik dan pemeliharaan fasilitas, pengelolaan limbah, gudang, ambulans, sistem informasi dan komunikasi, pemulasaran jenazah, sistem penanggulangan kebakaran, pengelolaan gas medik,dan pengelolaan air bersih.

j. Pelayanan rawat inap harus dilengkapi dengan fasilitas sebagai berikut :

- Jumlah tempat tidur perawatan kelas III paling sedikit $30 \%$ dari seluruh tempat tidur untuk rumah sakit pemerintah.

- Jumlah tempat tidur perawatan klas III paling sedikit $20 \%$ dari seluruh tempat tidur unuk rumah sakit swasta.

- Jumlah tempat tidur perawatan intensif sebanyak 5\% dari seluruh tempat tidur untuk rumah sakit milik pemerintah dan rumah sakit milik swasta.

Hasil penelitian menunjukkan bahwa di RSU GMIM Bethesda Tomohon, sudah ditempatkan di masing-masing fasilitas pelayanan kesehatan yang memenuhi syarat klasifikasi rumah sakit tipe $\mathrm{C}$, kecuali untuk dokter gigi spesialis belum ada dikarenakan belum adanya lembaga pendidikan formal yang menghasilkan alumni untuk dokter spesialis gigi.

Pada penelitian Nainggolan ${ }^{4}$ mengenai proses rekrutmen dan seleksi tenaga keperawatan di RS Santa Elisabeth Medan diperoleh hasil wawancara dengan informan secara mendalam bahwa hasil verifikasi setiap perawat dievaluasi kinerjanya dan dikelompokkan menjadi perawat senior dan perawat junior. Untuk tetap menjaga kualitas dan kemampuan perawat, maka rumah sakit tersebut juga mengadakan pelatihan bagi perawat yang diadakan di rumah sakit ataupun mengirim tenaga kesehatan para perawat yang dianggap mampu untuk mengikuti pelatihan di luar RS Santa Elisabeth Medan.

\section{Jumlah tenaga kesehatan di RSU GMIM Bethesda}

Dalam Permenkes no 56 tahun 2014 ditetapkan bahwa sumber daya manusia rumah sakit umum tipe $\mathrm{C}$ terdiri atas: ${ }^{6}$

a. Tenaga medis paling sedikit terdiri atas:

- 9 (sembilan) dokter umum untuk pelayanan medik dasar

- 2 (dua) dokter gigi umum untuk pelayanan medik gigi mulut

- 2 ( dua) dokter spesialis untuk setiap jenis pelayanan medik spesialis dasar

- 1 (satu) dokter spesialis intuk setiap jenis pelayanan medik spesialis penunjang

- 1 (satu) dokter gigi spesialis untuk setiap jenis pelayanan medik spesialis gigi mulut.

b. Tenaga kefarmasian paling sedikit terdiri atas:

- 1 ( satu) orang apoteker sebagai kepala instalasi farmasi rumah sakit

- 2 (dua) apoteker yang bertugas di rawat inap yang dibantu oleh paling sedikit 4 (empat) orang tenaga teknis kefarmasian

- 4 (empat) orang apoteker di rawat inap yang dibantu oleh paling sedikit 8 (delapan) orang tenaga teknis kefarmasian

- 1 (satu) orang apoteker sebagai koordinator penerimaan, distribusi dan produksi yang dapat merangkap melakukan pelayanan farmasi klinik di rawat inap atau rawat jalan dan dibantu oleh tenaga teknis kefarmasian yang jumlahnya disesuaikan dengan beban kerja pelayanan kefarmasian rumah sakit. 
Dari hasil wawancara dan observasi dokumen jumlah tenaga kesehatan RSU GMIM Bethesda sudah memenuhi persyaratan dari klasifikasi rumah sakit tipe $\mathrm{C}$, kecuali untuk tenaga medis yaitu dokter patologi klinik dan dokter gigi masih kurang yang masih bekerja paruh waktu/part time. Juga untuk tenaga apoteker masih sangat kurang yaitu 2 apoteker dan 4 asisten apoteker, sedangkan jumlah yang ditetapkan oleh Permenkes no 56 tahun 2014 ialah 8 untuk persyaratan rumah sakit tipe $\mathrm{C}$.

Hasil penelitian Marentek et al. $^{3}$ terhadap rekrutmen tenaga kesehatan di Dinas Kesehatan Kabupaten Minahasa Selatan mendapatkan dari hasil wawancara dengan informan secara mendalam bahwa proses pengelompokan tenaga kesehatan sebagai SDM di Dinas Kesehatan Kabupaten Minahasa Selatan dengan melihat data ketersediaan tenaga dari laporan data setiap puskesmas dan dilakukan analisis jabatan untuk melihat ketersediaan tenaga kesehatan ternyata masih sangat memerlukan tenaga kesehatan, terutama dokter gigi dan tenaga pranata laboratorium. Jumlah tenaga yang masih kurang dapat dikatakan untuk perencanaan dalam perekrutan yang dibuat belum sesuai dengan kebutuhan akan tenaga kesehatan dan belum memenuhi standar ketenagaan yang dibuat untuk kebutuhan tenaga di setiap rumah sakit maupun di puskesmas. ${ }^{3}$

\section{Tugas dan tanggung jawab tenaga kesehatan}

Dalam Undang-undang nomor 36 tahun 2014 dikatakan tenaga kesehatan yang telah ditempatkan di Fasilitas Kesehatan wajib melaksanakan tugas sesuai kompetensi dan kewenangannya. ${ }^{5}$ Kompetensi menjadi suatu bagian yang penting dalam pengembangan diri bagi seorang tenaga kesehatan dalam melaksanakan tugasnya sehingga akan tercapai tujuan dari pelayanan kesehatan yang diberikan rumah sakit. Untuk meningkatkan mutu praktik tenaga kesehatan dan untuk memberikan perlindungan dan kepastian hukum kepada tenaga kesehatan maka setiap tenaga kesehatan yang menjalankan praktik di bidang pelayanan kesehatan wajib memiliki STR yang diberikan oleh Konsil masingmasing tenaga kesehatan. Konsil tenaga kesehatan mempunyai fungsi pengaturan, penetapan dan pembinaan tenaga kesehatan dalam menjalankan praktek tenaga kesehatan. Setelah Konsil menerbitkan STR bagi tenaga kesehatan maka untuk menjalankan praktek di bidang kesehatan wajib memiliki ijin dalam bentuk SIP yang dikeluarkan oleh pemerintah daerah kabupaten/kota atas rekomendasi pejabat kesehatan yang berwewenang di kabupaten/kota tenpat tenaga kesehatan menjalankan prakteknya. Untuk menegakkan disiplin tenaga kesehatan dalam penyelenggaraan praktek tenaga kesehatan menurut UU no 36 tahun 2014 batas kewenangan kerja antara tenaga kesehatan dan asisten tenaga kesehatan harus jelas yaitu asisten tenaga kesehatan tidak boleh menjadi tenaga profesi melainkan menjadi tenaga pendamping tenaga kesehatan.

Pada penelitian ini didapatkan masih banyak pegawai lulusan SPK yang setara dengan sekolah menengah tidak memiliki STR yaitu 59 pegawai dimana 42 pegawai masih menjalani studi keperawatan Diploma/Ners dan 5 pegawai sudah ditempatkan dibagian administrasi karena sudah tidak mau mengikuti pendidikan lagi.

Kurniati dan Efendi ${ }^{2}$ mengatakan bahwa rendahnya kualitas SDM kesehatan dan kompetensi tenaga kesehatan berimplikasi pada rendahnya kualitas layanan yang diberikan dan lemahnya daya saing bangsa. Penguatan kompetensi SDM sebagai bagian utama dalam penguatan mutu tenaga kesehatan memerlukan keselarasan pola pembinaan pelatihan dan keterampilan kerja. Oleh sebab itu, diperlukan suatu lembaga standarisasi dan sertifikasi kompetensi kerja yang bersifat nasional dan diakui oleh semua pihak.

\section{SIMPULAN}

Dari hasil penelitian di RSU GMIM Bethesda dapat disimpulkan bahwa: 
1. Penempatan tenaga kesehatan di Rumah sakit Umum GMIM Bethesda sudah memenuhi persyaratan dan sesuai dengan kompetensi dan kewenangannya yaitu untuk asisten tenaga tidak boleh menjadi tenaga profesi dan hanya menjadi tenaga pendamping tenaga kesehatan.

2. Jenis tenaga kesehatan di RSU GMIM Bethesda sudah ditempatkan dan didistribusikan secara merata sesuai dengan kompetensi dan kewenangannya di masing-masing bidang pelayanan kesehatan sebagaimana yang menjadi ketentuan untuk rumah sakit tipe $\mathrm{C}$. Tenaga kesehatan medis yaitu dokter spesialis gigi belum terpenuhi dikarenakan belum adanya tenaga formal yang menghasilkan alumni untuk dokter spesialis gigi.

3. Jumlah tenaga kesehatan di RSU GMIM Bethesda sudah memenuhi persyaratan dari jumlah yang ditetapkan untuk klasifikasi rumah sakit tipe $\mathrm{C}$, kecuali dokter spesialis patologi klinik dan dokter gigi masih kurang, dan masih bekerja paruh waktu/part time. Tenaga apoteker juga masih sangat kurang yaitu 2 apoteker dan 4 asisten apoteker, sedangkan jumlah yang ditetapkan untuk tipe rumah sakit tipe $C$ ialah 8 apoteker.

4. Tugas dan tanggung jawab tenaga kesehatan yaitu setiap tenaga kesehatan dalam menjalankan praktek harus dilakukan sesuai dengan kewenangan yang didasarkan pada kompetensi yang dimilikinya.

\section{SARAN}

1. Bagi pemerintah kota Tomohon diharapkan adanya peningkatan mutu pelayanan khususnya memberikan perhatian yang tinggi terhadap tenaga kesehatan yang bekerja di RSU GMIM Bethesda dan lebih meningkatkan pengawasan pada pelayanan-pelayanan kesehatan yang ada di Kota Tomohon.

2. Bagi Manajemen RSU GMIM Bethesda diharapkan menempatkan asiten tenaga kesehatan sesuai dengan ketrampilan dan pengetahuannya sebagai asisten tenaga kesehatan karena penempatan di luar pengetahuan dan ketrampilan tenaga kesehatan adalah penyia-nyiaan dari sumber daya rumah sakit yang sudah menjadi pilar bagi rumah sakit Bethesda.

3. Bagi Ketua Yayasan diharapkan mampu memberikan pemeliharaan dan peningkatan jaminan ketenagaan yang lebih baik pada tenaga kesehatannya dengan memberi pelatihan-pelatihan bersertifikat untuk meningkatkan mutu pelayanan pada pasien.

\section{DAFTAR PUSTAKA}

1. Ardana KI, Mujiati N, Utama MW. Manajemen Sumber Daya Manusia. Yogyakarta: Graha Ilmu, 2012.

2. Kurniati A, Efendi F. Kajian SDM Kesehatan di Indonesia (5th ed). Jakarta: Salemba Medika, 2012.

3. Marentek CS, Mandagi CFK, Kolibu FK. Analisis rekrutmen tenaga kesehatan di Dinas Kesehatan Kabupaten Minahasa Selatan. Jurnal Ikmas. 2016;8(3).

4. Nainggolan SC. Proses rekrutmen dan seleksi tenaga keperawatan dalam peningkatan mutu pelayanan keperawatan Rumah Sakit Santa Elizabeth [Tesis]. Jakarta: Universitas Indonesia; 2011.

5. Undang-Undang Republik Indonesia Nomor 36 tentang tenaga kesehatan. Jakarta, 2014.

6. Peraturan Menteri Kesehatan Republik Indonesia Nomor 56 tentang klasifikasi dan perizinan rumah sakit. Jakarta: Depkes RI, 2014.

7. Zainuddin S. Reformasi sistem dan seleksi PNS (Perawat). Jakarta: Universitas Indonesia, 2011.

8. Ade SC, Pasinringi SA, Zulkifli A. Pengaruh faktor kepuasan kerja dan motivasi terhadap kinerja dokter di ruang RSUD Jayapura. Jurnal Manajemen dan Bisnis. 2014. Available from: pasca.unhas.ac.id 